\title{
A Multiple Criteria Decision Making Method to Weight the Sustainability Criteria of Equipment Selection for Surface Mining
}

\author{
Michał Patyk ${ }^{1}\left(\mathbb{D}\right.$, Przemysław Bodziony ${ }^{1}\left(\mathbb{D}\right.$ and Zbigniew Krysa ${ }^{2, *}$ \\ 1 Faculty of Mining and Geoengineering, AGH University of Science and Technology, al. Mickiewicza 30, \\ 30-059 Kraków, Poland; mpatyk@agh.edu.pl (M.P.); przembo@agh.edu.pl (P.B.) \\ 2 Faculty of Geoengineering, Mining and Geology, Wroclaw University of Technology, \\ Wybrzeże Wyspiańskiego 27, 50-370 Wrocław, Poland \\ * Correspondence: zbigniew.krysa@pwr.edu.pl
}

check for updates

Citation: Patyk, M.; Bodziony, P.; Krysa, Z. A Multiple Criteria Decision Making Method to Weight the Sustainability Criteria of Equipment Selection for Surface Mining. Energies 2021, 14, 3066. https://doi.org/ $10.3390 /$ en14113066

Academic Editor: Sergey Zhironkin

Received: 28 March 2021

Accepted: 20 May 2021

Published: 25 May 2021

Publisher's Note: MDPI stays neutral with regard to jurisdictional claims in published maps and institutional affiliations.

Copyright: (c) 2021 by the authors. Licensee MDPI, Basel, Switzerland. This article is an open access article distributed under the terms and conditions of the Creative Commons Attribution (CC BY) license (https:// creativecommons.org/licenses/by/ $4.0 /)$.

\begin{abstract}
Selection and assessment of mining equipment used in open pit rock mines relies chiefly on estimates of overall exploitation cost. The rational arrangement of mining equipment and systems comprising loading machines, haul trucks and crushing plants should be preceded by a thorough analysis of technical and economic aspects, such as investment outlays and the costs of further exploitation, which largely determine the costs of mining operations and the deposit value. Additionally, the operational parameters of the mining equipment ought to be considered. In this study, a universal set of evaluation criteria has been developed, and an evaluation method has been applied for the selection of surface mining equipment and the processing system to be operated in specific mining conditions, defined by the user. The objective of this study is to develop and apply the new methodology of multi-criteria selection of open pit rock mining equipment based on multiple criteria decision-making (MCDM) procedures, to enable the optimization of loading, handling and crushing processes. The methodology, underpinned by the principles of MCDM, provides the dedicated ranking procedures, including the ELECTRE III. The applied methodology allows the alternative options (variants) to be ranked accordingly. Ultimately, a more universal methodology is developed, applicable in other surface mines where geological and mining conditions are similar. It may prove particularly useful in selection and performance assessment of mining equipment and process line configurations in mining of low-quality rock deposits. Therefore, we undertook to develop universal criteria and applications for the selection and performance assessment of process machines for surface mines, taking into account environmental aspects as well as deposit quality.
\end{abstract}

Keywords: surface mining; mining equipment; multiple criteria decision making (MCDM); ELECTRE III

\section{Introduction}

The profitability of rock production mining is closely linked to the individual components of the machine's working process. The rational selection of mining system configurations including vehicles and loading and processing machines should be based on a thorough technological and economic analysis that factors in mining conditions. The selection of machines should take into consideration all key elements specific for mining process [1]. Stevanovic et al. [2] recognize that geological conditions are essential to assessing the se-lection of a mining system and consider them the most important among 6 other criteria. Of particular importance in selection of the process line system is the exact number, type and operating capacity of machinery and equipment. Any over- or underestimation may adversely and irreversibly impact on the net value of the entire mining project, hence the quest for reliable methods for selecting machines based on precise and exact criteria [3]. Choosing the optimal mining equipment is challenging problems and depends on many criteria and the applied method of selecting machines: deterministic where fleet 
size is the function of production requirements and more complex taking into account uncertainty based on approximation algorithms and stochastic models [4]. Voronov et al. [5] indicate that the optimal selection of machines is a formidable task, requiring vast amounts of input data especially in the case of mixed equipment fleets. Selection of mining equipment has received a great deal of attention, and the problem has grown in importance lately as the quality of deposits to be mined has deteriorated. Samanta et al. [6] based on the case of mining equipment selection notice that large numbers of factors can lead to unrealistic outcome or difficulty in making criteria comparison. In real life situations, the fact that information is unavailable or incomplete may result in data (attributes) being not deterministic but fuzzy-imprecise [3].

Exploitation of low-quality deposits is a vitally important and topical issue. Low quality deposits or deposit sections, containing various kinds of inclusions (e.g., karstic formations), are, in current mining practice, either not exploited or hauled to rock dumping sites for selective dumping, leaving the possibility of their exploitation at a later stage. However, this process does not contribute to the sustainable exploitation of the deposit but helps postpone the problem of re-exploitation.

Therefore, in the case of low-quality deposits, it is necessary to strive for sustainable exploitation and the best possible use of the entire deposit in parallel with the target deposit, which may contribute to increasing extraction and extending mine life [7-9]. In addition, the use of such deposits or parts of deposits reduces the amount of dumped material and the size of the dumps, which translates into lower waste generation and long-term sustainable management of the deposit [10,11], especially since the exploitation of lowquality deposits may be profitable [12]. The mining sector is responsible for GHG emissions from the operating mining equipment and from electricity generation still reliant on fossil fuels. The global demand for minerals is increasing steadily and the process routes in mineral extraction require larger amounts of energy to extract and process minerals from low-quality deposits, and hence the emission levels are rising [13].

Selection of mining equipment is a complex multi-criteria decision problem. The main objective of this study is to develop new interdisciplinary criteria taking into account both tangible and intangible aspects, and to explore potential applications of the MultipleCriteria Decision-Making (MCDM) tool, such as to facilitate the optimal selection of environment friendly equipment that should satisfy the involved decision makers. Identification of relevant factors is the crucial step in decision making and optimization process, particularly in the case of low-quality deposits, when the quality criterion determines the actual price which may be close to the production costs. In this economic perspective the problem of low-quality deposits is similar to exploitation of small deposits, specifically to the mining of minerals for modern technology (rare earth elements) [14]. The fact that the output is relatively small is of major importance to decision-makers especially in the context of capital expenditures, a large proportion of which are the costs of mining equipment.

\section{Materials and Methods}

This article explores the feasibility of using three variants of mining equipment layout for the exploitation of low-quality deposits. Analyses carried out in the mine have shown that it is possible to separate karst fraction from the rest of the deposit material by means of preliminary crushing. The karst is located mainly in the $0-40 \mathrm{~mm}$ fraction and constitutes about $20 \%$ of the analyzed part of the deposit. This means that about $20 \%$ is not suitable for further use in the production process and must be transported to the dump. However, around $80 \%$ of the material can be used. The analyses showed that it is possible to separate karst fraction from the rest of the deposit material by preliminary crushing.

A set of criteria having relevance to evaluation and selection of open pit mining equipment are presented below. Relying on the MCDM approach, they can be effectively used to solve discrete multiple criteria decision problems, such as ranking problems. The group of 8 criteria and is subdivided into 4 subsets, covering the environmental, economic, technological aspects as well as mining operations and reliability. In consideration of those 
aspects, we undertook to develop universal criteria and applications for the selec-tion and assessment of process machines for surface mines, including low-quality deposits, sustainability and environmental issues. The applications of MCDM in solving issues of sustainable development are currently important topics of research and were described by Siksnelyte, et al. [15], Kumar et al. [16] and Trojanowska and Nęcka [17]. For this reason, environmental and energy consumption aspects are taken into account when defining the criteria that describe the decision model.

The main focus is on applications of Multiple-Criteria Decision-Making (MCDM) tools, including one of the related MCDM methods-ELECTRE III. A method is proposed for ranking the set of alternatives to be evaluated basing on multiple and conflicting crite-ria, organized in a hierarchical structure. This hierarchy allows the decision-maker to identify various intermediate sub-problems to be addressed. Consequently, the analysis of the criteria is carried out according to the subsets defined in the hierarchy and following the precedence relations principle in the bottom-up approach. To effectively handle such hierarchical structures, the application of the extended ELECTRE-III is recommended. According to Hokkanen et al. [18] ELECTRE III is a most effective outranking methodology as it uses thresholds for modelling of imprecise data. Thus, alternative solutions (alternatives) applicable to surface mining machine systems can be sorted and ranked accordingly. The proposed methods are universally applicable to other types of mines [19].

They rely on a number of criteria allowing the user's preference options to be stated (i.e., strict, weak, low or indifferent) such that the value of a membership function should be derived. The ELECTRE III, based on a fuzzy outranking relationship, was developed to handle ranking problem, such as evaluation of the mining equipment layout in the specified mining conditions encountered in open pit mines where the deposits are of poor quality.

This study showcases the applications of ELECTRE III, which are more widespread than those of the simpler ELECTRE methods, to be used when handling similar problems, especially in the area of mining engineering, mechanical engineering, manufacturing systems and logistics and supply chains. Sitorus et al. [20] carried out a thorough overview on publications in the field of MCDM methods and their applications to mining and mineral processing and established that by 2018 the use of MCDM was reported in 90 studies whilst 24 out of them had relevance to mining equipment. The author of one paper [1] reported on the use of ELECTRE method. Most of the MCDM solutions in the sub-field of equipment selection were implemented using the AHP or hybrid method. Sousa et al. [21] used the ELECTRE I and PROMETHEE II method to select haul trucks to transport the ore in one of the Brazilian mines. The combination of the AHP and ELECTRE methods presents Stojanovic et al. [22] showing the application of the choice of operating technology for coal deposit. The AHP is used to handle the selection problem, the PROMETHEE effectively deals with ranking questions whilst ELECTRE III is able to handle both the ranking and sorting problems [23]. Nevertheless, as Hodget showed on the example of chemical manufacturing process, MCDM method may lead to different or no results for the same input data [24]. To conclude, our findings can be summarized recalling a quotation from Figueira et al. [25] who declared that research on ELECTRE III methods is far from being a dead field. It is just the opposite: the method is evolving and gains popularity, extending to new areas of expertise, supported by methodological and theoretical developments and dedicated user-friendly software implementations.

The step-by-step procedures recalled in this case study is outlined. The ELECTRE III method allows us to rank the finite set $A$ of variants, evaluated according to a consistent set of criteria [26-28]. The variants are ranked according to the outranking relationship, denoted by $S$. Variant a is assumed to outrank variant $b$, which is denoted by $a S b$, as long as the available information on the decision maker's preferences, effectiveness (quality) of the variant evaluation and on the specific aspects of the problem provides sufficient evidence to prove that variant $a$ is at least as good as $b$, unless there are valid reasons to reject this assumption $[29,30]$. The calculation procedure in the ELECTRE III method involves the following four stages: 
- Construction of the decision maker's model of preferences with regard to particular criteria, including the definition of the respective weights and threshold values.

- Derivation of the valued outranking relationship-S.

- Variant ranking according to outranking relationships.

- $\quad$ Final ranking of variants.

The ELECTRE III method allows the decision-maker to express four states of preference when comparing variants $a$ and $b$ :

- Indifference, denoted by alb.

- Weak preference for variant $a$ over variant $b$, denoted by $a Q b$.

- Strong preference for variant $a$ over variant $b$, denoted by $a P b$.

- Incomparability of variants $a$ and $b$, denoted by $a J b$.

Three thresholds are set to model these states of preference, determined separately for each j-criterion: threshold of indifference $-q_{j}$, threshold of preference $-p_{j}$ and veto threshold $-v_{j}$. In addition, the relative importance of individual criteria is expressed by their respective weighting factors $-k_{j}$.

The outranking relationship evaluates the degree of credibility that a should be at least as good as $b$, which is denoted by the concordance index $c(a, b)$, whilst the discordance condition with respect to the relationship $S(a, b)$ is expressed by the discordance index $D j$ $(a, b)$ (Figure 1).

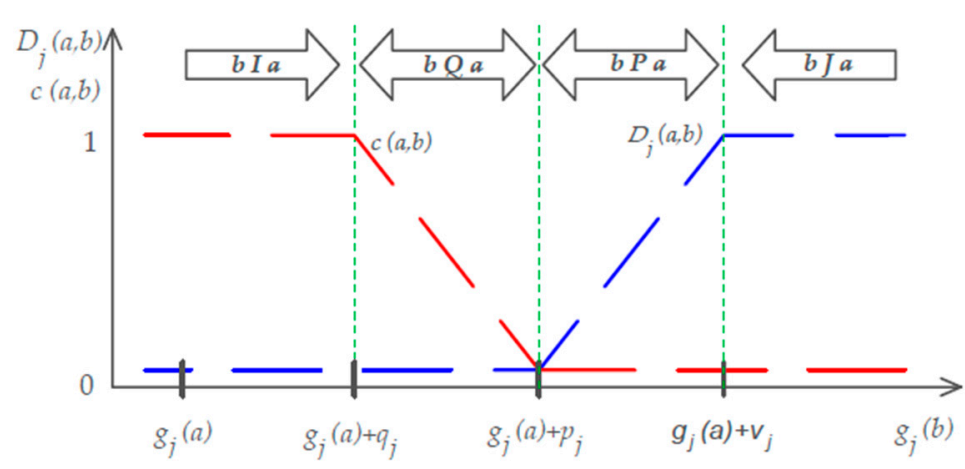

Figure 1. The four-state preference model (indifference $I$, weak preference $Q$, strong preference $P$, incomparability $J$ ) constructed on the basis of threshold values $q_{j}, p_{j}, v_{j}$ [31].

An obvious advantage of using valued outranking relationships is that they are largely insensitive to parameter changes, both arbitrary and necessary ones.

The final ranking of variants in the ELECTRE III method is based on joining the descending and ascending distillations. The result is one complete preorder, in the form of a graph, which is the final ranking of the analyzed variants, showing the relations between them. The ELECTRE III method allows the conflicting criteria to be incorporated into a single analytical procedure. Even though the ELECTRE III method may appear fairly complicated, dedicated software is available to facilitate the procedure [32].

\section{Results}

The following aspects were taken into consideration when constructing the family of criteria and completing the set of alternatives, and in selection of the ranking method and implementations of the user preference models:

- Complexity and intricate nature o of evaluation criteria.

- Implementation of several decision-makers' preference models, the decision-makers acting as independent experts.

- Preference models giving the relative weight of each criterion, as well as the relationship between the weak and strong preference, and indifference between the alternatives being evaluated. 
- Uncertainty on the part of decision makers as to whether the analyzed variants and preference thresholds should be regarded as incomparable.

- The significance of modelling of the decision-making processes, requiring a repeated reliability analysis.

\subsection{Designing Decision Variants}

In the case of karstic formations, ungraded material (barren rock) accounts for $20 \%$ of the limestone deposit. The term "deposit quality 80 " used in our paper means that the limestone content in the intermediate product is $80 \%$, assuming that the rock extracted from the deposit should be preliminarily crushed to remove the karst fractions with the grain size of $0-40 \mathrm{~mm}$ from the final product. The grain size in the fraction that is to be further processed (intermediate product) exceeds $40 \mathrm{~mm}$ [33].

In karstic formations, $20 \%$ of the limestone deposit under study comprises ungraded material (barren rock), which is unfit for use further in the process. In our study, we used the term "deposit quality 80 ", meaning that the intermediate product consists in $80 \%$ of limestone, and assuming that the rock extracted from the deposit should be preliminarily crushed in order to remove the karst fraction with a particular size distribution of $0-40 \mathrm{~mm}$ from the final material. The fraction that is fit for use further in the process (intermediate product) has a particular size distribution of more than $40 \mathrm{~mm}$ [33].

Three Decision Variants of the processing systems to be deployed have been proposed, making use of machines currently operated in the mine. The primary crushing operations will take place either in an electric-powered mobile crusher (MC) or in a diesel powered or stationary crusher (SC2), depending on the decision variant. The excavated material can be loaded onto the mobile crusher (MC) by a hydraulic excavator (E), whilst wheeled loaders (WL) will be used to load it onto the haulage trucks (HT). Depending on the decision variant, trucks will be deployed to:

- Transport the excavated to the primary crusher (SC2 or MC).

- Transport excavated material to Aggregate Mining Plant (AMP).

- Transport the extracted rock to the external dump (ED).

In the decision variant no. 2 belt conveyor (BC) was also used for the transport of intermediate product between the excavation site and Aggregate Mining Plant (AMP).

Schematics of all decision variants were presented at the Figures 2-4 [33].

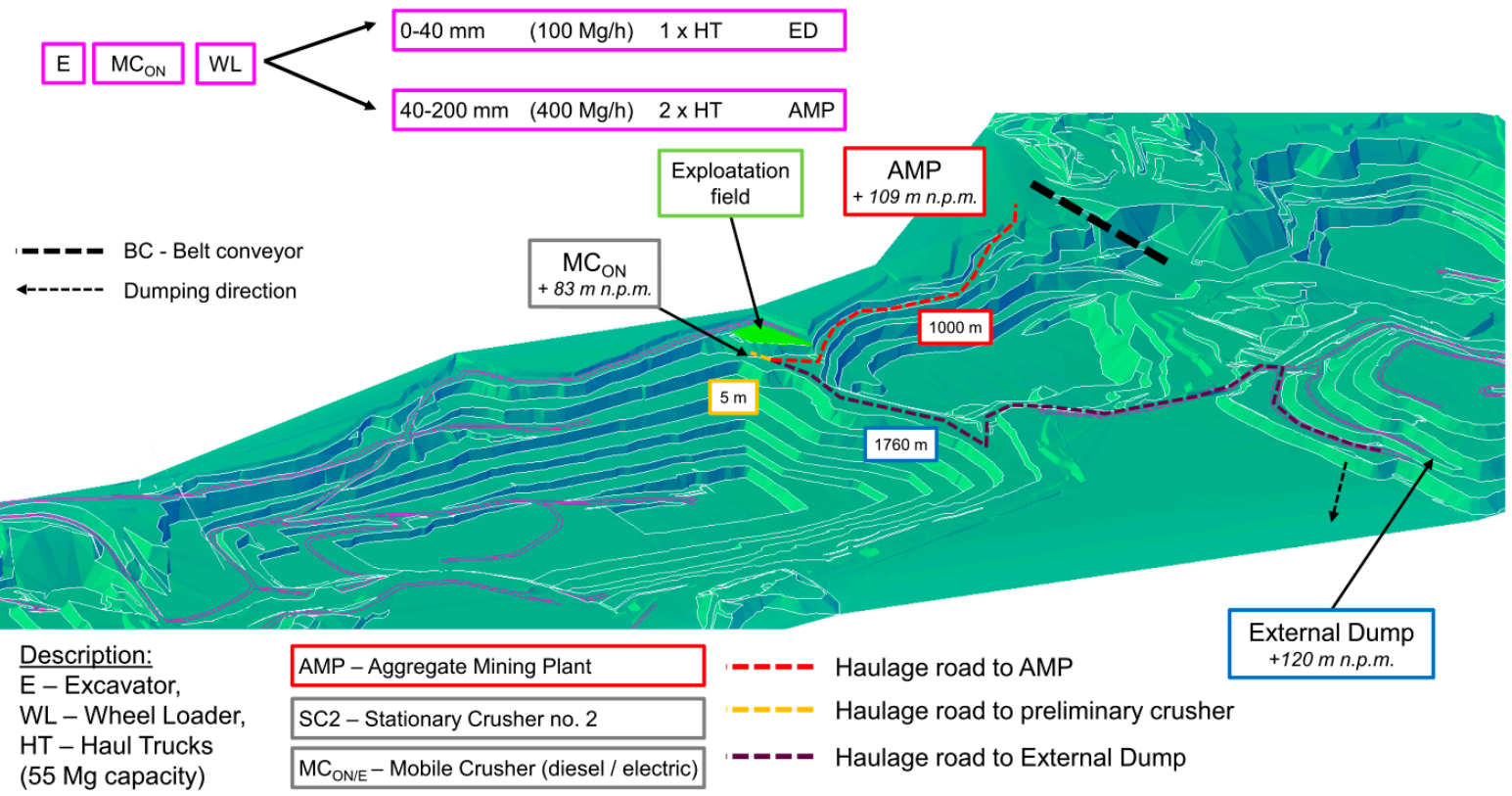

Figure 2. Primary crusher locations in the analyzed mine--Decision Variants no. 1. 


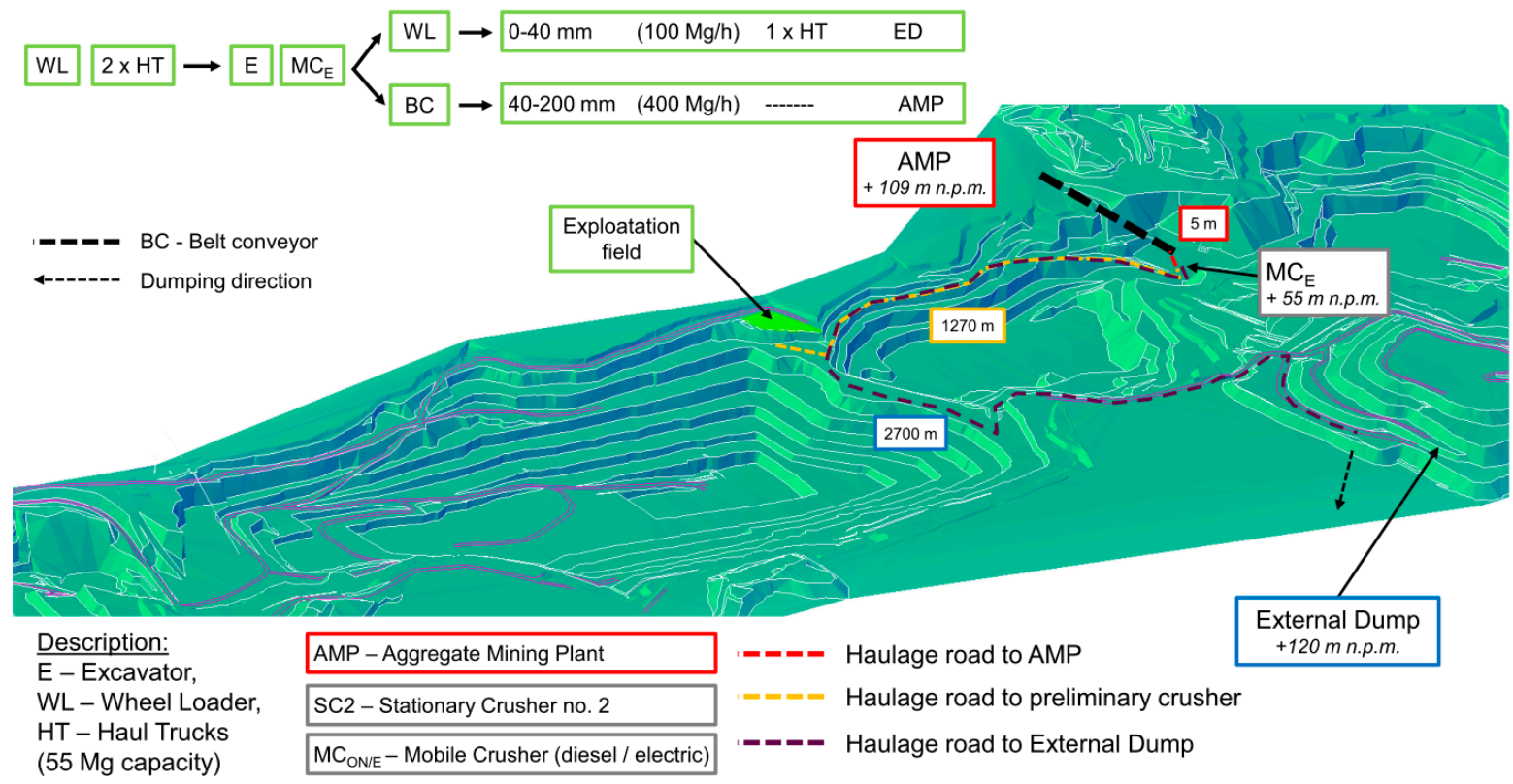

Figure 3. Primary crusher locations in the analyzed mine-Decision Variants no. 2.

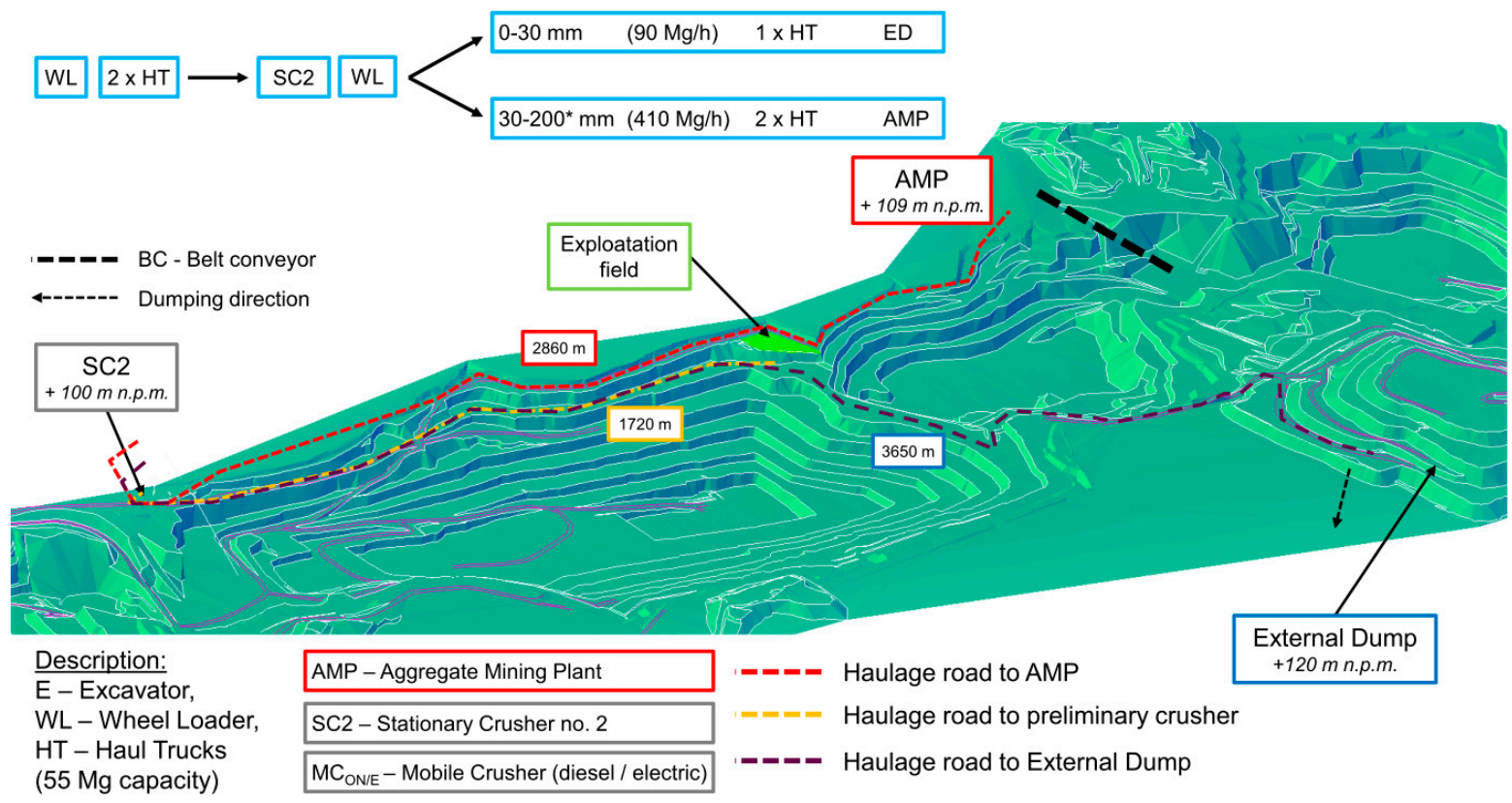

Figure 4. Primary crusher locations in the analyzed mine-Decision Variants no. 3.

The main difference between decision variant no. 1 and no. 2 is requirements for the movement and transport mobile crusher (MC) to the different points in the mine. This is necessary because of the blasting methods in this type of mining (see Figures 2 and 3).

In all variants, mining operations continued for two working shifts, the number of working hours per one shift is assumed to be 7 (total working hours).

\subsection{Criteria for Selection and Evaluation of Mining Equipment in Open Pit Rock Mines}

The family of criteria having relevance to evaluation and selection of the mining equipment are summarized below. A comprehensive analysis of the decision-making problem relies on a set of consistent criteria, covering the engineering, economic, environmental and operational aspects as well as reliability issues.

- $\quad$ K1-length of transport routes. 
- $\quad \mathrm{K} 2$ - machine fleet size.

- K3-reliability index.

- $\quad \mathrm{K} 4$ - distance of the crushing unit from residential buildings.

- $\quad \mathrm{K} 5$ - energy consumption by the mining equipment.

- $\mathrm{K} 6-\mathrm{CO}$ emissions from the mining equipment.

- $\quad$ K7-size of external dump.

- $\quad \mathrm{K} 8$-process-related costs.

\subsubsection{Technology-Related Criteria}

K1-Length of transport routes-a minimized quantifiable criterion that determines the total number of kilometers covered by vehicles, including haulage trucks and a belt conveyor, during two working shifts, expressed in $(\mathrm{km})$;

K2-Machine fleet size - a minimized quantifiable criterion that determines the total number of machines making up the fleet (decision alternative), expressed in (pcs) (Table 1);

Table 1. Number of machines in each variant [12].

\begin{tabular}{ccccc}
\hline Machine Type & Name & W1 & W2 & W3 \\
\hline haul truck & Komatsu HD 465 & 3 & 3 & 5 \\
excavator & CAT 34 & 1 & 1 & - \\
wheel loader & Komatsu WA600 HL & 1 & 2 & 2 \\
mobile crusher diesel & Powerscreen & 1 & - & - \\
Premiertrak 1180 & Powerscreen & - & 1 & - \\
mobile crusher electric & Premiertrak 1180 & - & - & 1 \\
stationary crusher & - & - & 1 & 1 \\
belt conveyor & - & 6 & 8 & 8 \\
\hline total & - & &
\end{tabular}

\subsubsection{Exploitation and Reliability Criterion}

K3-Reliability index $K_{g t}$ - a maximized criterion expressing the probability that a given machine or system should be operational and running at a specified time. It has to be obtained for each type of equipment that make up the mining machine system, expressed as the mean value for all types of machines (haulage trucks, loaders and processing machines). The reliability index is expressed in (\%).

$$
K_{g t}=\frac{\sum_{i=1}^{n} t_{i}{ }^{(j)}}{\sum_{i=1}^{n} t_{i}\left({ }^{(j)}+\sum_{i=1}^{n} t_{i}^{(n)}\right.}
$$

where: $t_{i}^{(j)}$-effective working time in $i$-th day of operation $(\mathrm{h}), t_{i}^{\left({ }^{(n)}\right.}$-time required for repairs and maintenance, including:

$$
\sum_{i=1}^{n} t_{i}^{(n)}=t_{e r}+t_{e s}+t_{w d}
$$

$t_{e r}$-effective repair downtime (h), $t_{e s}$-repairs done by external services (h), $t_{w d}$-workshop downtime (h).

A comprehensive analysis of a decision-making problem requires a consistent family of criteria covering technological, environmental and economic aspects.

\subsubsection{Environmental Criteria}

K4-Distance from the crushing unit to residential buildings-a maximized quantifiable criterion that determines the distance of the preliminary crushing site (crusher's location) to the nearest residential buildings, expressed in meters, constituting the basis for establishing the nuisance zone associated with noise, vibration and dust emissions. 
K5-Energy/power consumption by the mining equipment-a minimized quantifiable criterion that determines the total energy expenditure by mining and processing machines, expressed in (MJ/day). It allows for identification of those machines and systems that cause the lowest degree environmental nuisance due to the lowest energy consumption during two working shifts. Fuel consumption during the ride by haulage trucks depends on the length and configuration of haulage roads.

$\mathrm{K} 6$ - $\mathrm{CO}$ emissions from the mining equipment-a minimized quantifiable criterion that determines the total amount of $\mathrm{CO}$ emissions by a machine or system, expressed in $(\mathrm{g} / \mathrm{kWh})$. It enables the identification of mining machines and systems that produce the least environmental nuisance in terms of car-bon monoxide emissions-i.e., which mining machine or system is responsible for the $\mathrm{CO}$ lowest emission during two working shifts, based on telemetry data (Table 2). $\mathrm{CO}$ emissions are considered instead of $\mathrm{CO}_{2}$ or $\mathrm{NOx}$ since a common benchmark is required to compare emissions from different sources. Direct emissions produced by the machine were considered in this study, without analyzing the emissions related to the value chain e.g., as in the case of electric systems.

Table 2. Fuel and energy consumption and CO emissions by mining equipment [12,34-37].

\begin{tabular}{cccc}
\hline Machine Type/Name & $\begin{array}{c}\text { Power Installed } \\
(\mathbf{k W})\end{array}$ & $\begin{array}{c}\text { Av. Consumption } \\
\text { of Energy Carriers }\end{array}$ & $\begin{array}{c}\text { CO Emissions } \\
\text { (g/kWh) }\end{array}$ \\
\hline $\begin{array}{c}\text { excavator/CAT 349 } \\
\text { wheel loader/Komatsu WA600 }\end{array}$ & 317 & $391 / \mathrm{h}$ & 6.5 \\
HL & 393 & $401 / \mathrm{h}$ & 3.5 \\
$\begin{array}{c}\text { haul trucks/Komatsu HD 465 } \\
\text { mobile crusher plant } \\
\text { (diesel)/Powerscreen } \\
\begin{array}{c}\text { Premiertrak 1180 } \\
\text { mobile crusher plant }\end{array}\end{array}$ & 551 & $38 \mathrm{l} / \mathrm{h}$ & 3.5 \\
$\begin{array}{c}\text { (electric)/Powerscreen } \\
\text { Premiertrak 1180 } \\
\text { belt conveyor }\end{array}$ & 205 & $28 \mathrm{l} / \mathrm{h}$ & \\
$\begin{array}{c}\text { preliminary crushing } \\
\text { rectangular screen } \\
\text { stationary Crusher no. 2 } \\
\text { stationary plant }\end{array}$ & 185 & $148 \mathrm{~kW} / \mathrm{h}$ & zero emission \\
\hline
\end{tabular}

K7-Size of external dump-a minimized quantifiable criterion that determines the amount of waste rock dumped during one working shift, expressed in (Mg). It quantifies the amount of material dumped within the area of the mine, which is a major determinant of the actual size of the dumping site, embracing additional environmental fees and transport costs, as well as dumping costs.

\subsubsection{Economic Criteria}

K8-Process-related costs-a minimized quantifiable economic criterion related to the aggregation of all significant costs borne to obtain the intermediate product and ungraded material, i.e., all the constituent costs generated by the mining equipment during a working shift, expressed in (EUR/day).

For the purposes of the ELECTRE III method, a matrix of criteria values was constructed (Table 3). In order to assess and select an optimum mining machine system, we conducted in-depth interviews with three experts-a senior mine manager (E1) (Table 4, Figure 5a), a mine maintenance manager (E2) (Table 5, Figure 5b), an academic expert whose area of research is surface mining (E3) (Table 6, Figure 5c) and a local government official expert on environment (E4) (Table 7, Figure 5d). Accordingly, each expert was asked to define the relative importance of all the criteria and the preference levels and to include them in the decision thresholds $q_{i}$-indifference, $p_{i}$-preference, $v_{i}$-veto. 
Table 3. Values of the specified common family of criteria (criteria evaluation matrix)—final values of the criteria for each analyzed variant (mining machines and systems).

\begin{tabular}{|c|c|c|c|c|c|c|c|c|}
\hline & K1 & K2 & K3 & K4 & K5 & K6 & K7 & K8 \\
\hline Criteria & $\begin{array}{l}\text { Length of } \\
\text { Transport } \\
\text { Routes }\end{array}$ & $\begin{array}{l}\text { Machine } \\
\text { Fleet Size }\end{array}$ & $\begin{array}{l}\text { Reliability } \\
\text { Index }\end{array}$ & $\begin{array}{l}\text { Distance of the } \\
\text { Crushing Unit }\end{array}$ & $\begin{array}{c}\text { Energy } \\
\text { Consumption }\end{array}$ & $\begin{array}{c}\mathrm{CO} \\
\text { Emissions }\end{array}$ & $\begin{array}{l}\text { Size of External } \\
\text { Dump }\end{array}$ & $\begin{array}{l}\text { Process-Related } \\
\text { Costs }\end{array}$ \\
\hline unit & $\mathrm{km} /$ day & pcs. & $\%$ & $\mathrm{~m}$ & MJ/day & $\mathrm{g} / \mathrm{kWh}$ & $\mathrm{Mg}$ & EUR/day \\
\hline preference & $\min$ & $\min$ & $\max$ & $\max$ & $\min$ & $\min$ & $\min$ & $\min$ \\
\hline W1 & 454 & 6 & 93.1 & 2192 & 103,194 & 90.70 & 1400 & 732 \\
\hline W2 & 570 & 8 & 94.0 & 1190 & 125,925 & 95.67 & 1400 & 991 \\
\hline W3 & 2181 & 8 & 93.6 & 1975 & 170,885 & 125.84 & 1260 & 1304 \\
\hline
\end{tabular}

Table 4. Decision-maker's preference model-Expert 1-Mine Manager, Chief Executive Officer.

\begin{tabular}{lccccc}
\hline No. & $\begin{array}{c}\text { Preference } \\
\text { Direction }\end{array}$ & $\begin{array}{c}\text { Indifference } \\
\text { Threshold }\end{array}$ & $\begin{array}{c}\text { Preference } \\
\text { Threshold }\end{array}$ & $\begin{array}{c}\text { Veto } \\
\text { Threshold }\end{array}$ & $\begin{array}{c}\text { Relative } \\
\text { Importance }\end{array}$ \\
\hline K1 & min & 25 & 50 & 100 & 8 \\
K2 & min & 0 & 1 & 2 & 4 \\
K3 & $\max$ & 0.5 & 0.75 & 1 & 5 \\
K4 & max & 100 & 200 & 500 & 9 \\
K5 & min & 1000 & 15,000 & 20,000 & 6 \\
K6 & min & 2 & 6 & 25 & 6 \\
K7 & min & 30 & 600 & 1000 & 7 \\
K8 & min & 120 & 240 & 600 & 8 \\
\hline
\end{tabular}

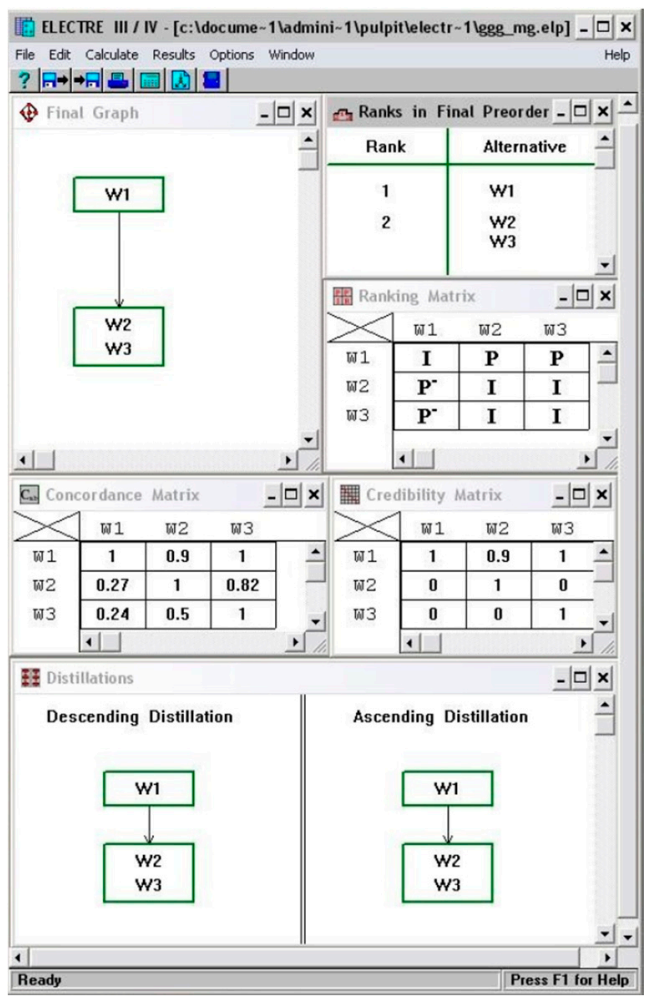

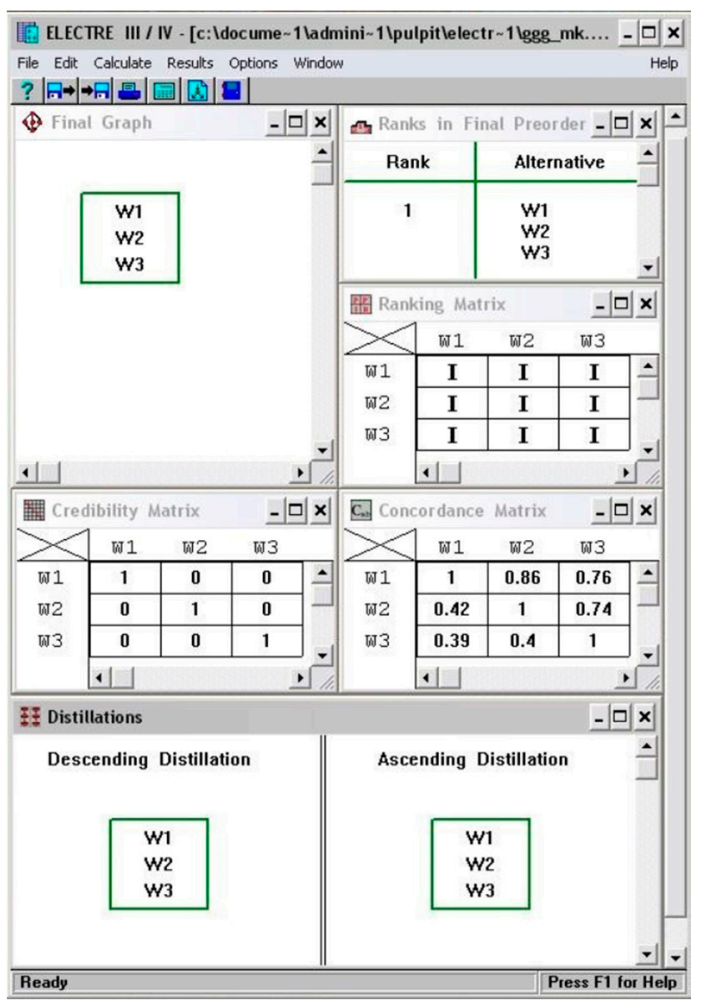

(a)

(b)

Figure 5. Cont. 


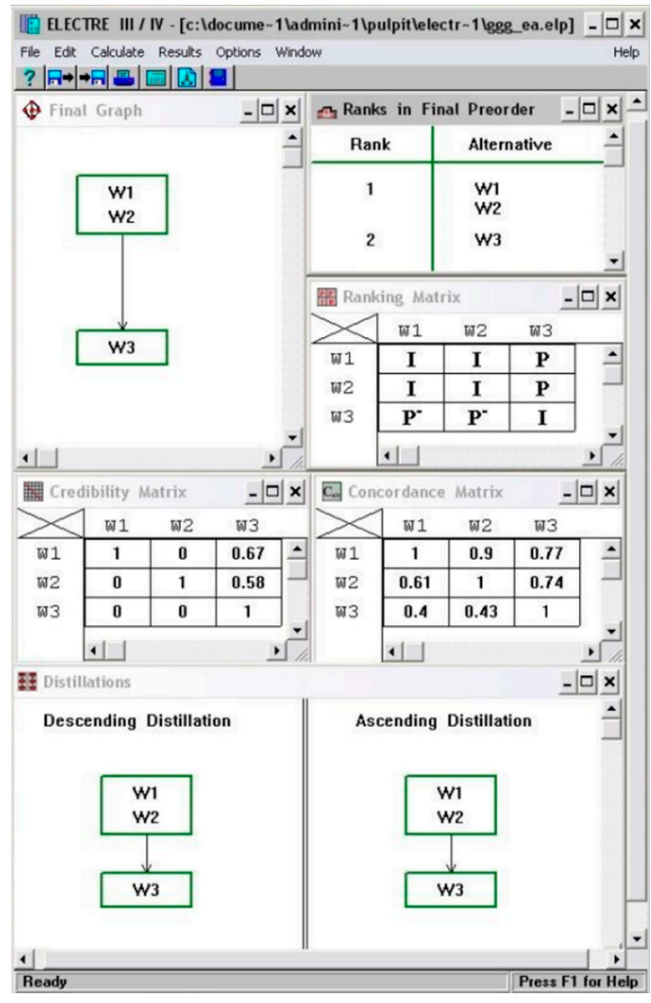

(c)

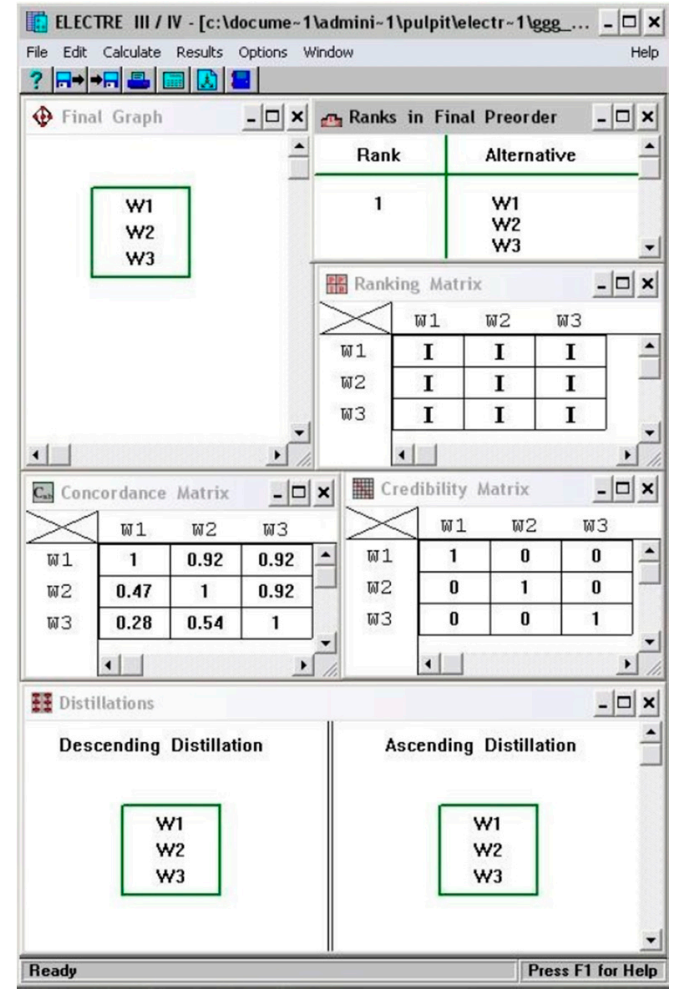

(d)

Figure 5. Final rankings, outranking, credibility and concordance matrices for the experts' preference models: (a) E1, (b) E2, (c) E3, (d) E4.

Table 5. Decision-maker's preference model-Expert 2-Mine Manager-Mining Operations Manager.

\begin{tabular}{cccccc}
\hline No. & $\begin{array}{c}\text { Preference } \\
\text { Direction }\end{array}$ & $\begin{array}{c}\text { Indifference } \\
\text { Threshold }\end{array}$ & $\begin{array}{c}\text { Preference } \\
\text { Threshold }\end{array}$ & $\begin{array}{c}\text { Veto } \\
\text { Threshold }\end{array}$ & $\begin{array}{c}\text { Relative } \\
\text { Importance }\end{array}$ \\
\hline K1 & min & 200 & 500 & 1000 & 7 \\
K2 & min & 1 & 2 & 4 & 7 \\
K3 & max & 0.1 & 0.3 & 0.5 & 7 \\
K4 & max & 200 & 400 & 650 & 8 \\
K5 & min & 2500 & 20,000 & 50,000 & 5 \\
K6 & min & 10 & 15 & 20 & 2 \\
K7 & min & 60 & 100 & 200 & 5 \\
K8 & min & 30 & 60 & 120 & 9 \\
\hline
\end{tabular}

Table 6. Decision-maker's preference model-Expert 3-academic expert.

\begin{tabular}{cccccc}
\hline No. & $\begin{array}{c}\text { Preference } \\
\text { Direction }\end{array}$ & $\begin{array}{c}\text { Indifference } \\
\text { Threshold }\end{array}$ & $\begin{array}{c}\text { Preference } \\
\text { Threshold }\end{array}$ & $\begin{array}{c}\text { Veto } \\
\text { Threshold }\end{array}$ & $\begin{array}{c}\text { Relative } \\
\text { Importance }\end{array}$ \\
\hline K1 & min & 100 & 300 & 500 & 5 \\
K2 & min & 1 & 3 & 5 & 3 \\
K3 & $\max$ & 0.2 & 0.5 & 0.7 & 5 \\
K4 & $\max$ & 1300 & 500 & 1000 & 5 \\
K5 & min & 3000 & 10,000 & 30,000 & 4 \\
K6 & min & 5 & 10 & 20 & 4 \\
K7 & min & 50 & 100 & 150 & 5 \\
K8 & min & 180 & 360 & 720 & 9 \\
\hline
\end{tabular}


Table 7. Decision-maker's preference model—Expert 4-local government official expert on environment.

\begin{tabular}{cccccc}
\hline No. & $\begin{array}{c}\text { Preference } \\
\text { Direction }\end{array}$ & $\begin{array}{c}\text { Indifference } \\
\text { Threshold }\end{array}$ & $\begin{array}{c}\text { Preference } \\
\text { Threshold }\end{array}$ & $\begin{array}{c}\text { Veto } \\
\text { Threshold }\end{array}$ & $\begin{array}{c}\text { Relative } \\
\text { Importance }\end{array}$ \\
\hline K1 & min & 25 & 50 & 100 & 8 \\
K2 & $\min$ & 1 & 2 & 4 & 6 \\
K3 & $\max$ & 0.05 & 0.35 & 0.75 & 4 \\
K4 & $\max$ & 300 & 600 & 1200 & 8 \\
K5 & $\min$ & 3750 & 7500 & 15,000 & 4 \\
K6 & $\min$ & 5 & 10 & 25 & 9 \\
K7 & $\min$ & 30 & 60 & 120 & 8 \\
K8 & min & 60 & 120 & 240 & 2 \\
\hline
\end{tabular}

Preference levels stated by decision-makers are collated in Tables 4-7. Preference directions of each of the criteria ( $\min$ or max value) are included, indicating minimization or maximization of the value of the criterion.

The values of the relative weights of the criteria, accepted in accordance with the preferences of the decision-maker, are presented in Table 8.

Table 8. Relative and average importance of the criteria considered by experts (E1-E4).

\begin{tabular}{ccccccc}
\hline No. & Preference Direction & E1 & E2 & E3 & E4 & Average \\
\hline K1 & $\min$ & 8 & 7 & 5 & 8 & 7 \\
K2 & $\min$ & 4 & 7 & 3 & 6 & 5 \\
K3 & $\max$ & 5 & 7 & 4 & 4 & 5.25 \\
K4 & $\max$ & 9 & 8 & 5 & 8 & 7.5 \\
K5 & $\min$ & 6 & 5 & 4 & 4 & 4.75 \\
K6 & $\min$ & 6 & 2 & 4 & 9 & 5.25 \\
K7 & $\min$ & 7 & 5 & 5 & 8 & 6.25 \\
K8 & $\min$ & 8 & 9 & 9 & 2 & 7 \\
\hline
\end{tabular}

These models of decision-makers' preferences were constructed independent of each other, without consultations between experts. In addition, an expert data analyst was called in to identify, explain and create an underlying mathematical model with regard to respective fields of expertise and to select all methods that should enable the solution of the given decision problem. Accordingly, four final rankings were generated, for each of the adopted preference models, respectively (Figure 5).

The final order for expert E1 (Mine Manager and Chief Executive Officer) indicates that for the preference model in question, alternative W1 outranks all other alternatives and is therefore the most advantageous solution. Alternatives W2 and W3 are indistinguishable from each other. For expert E2 (Mining Operations Manager) and E4 (local government official expert on environment), all variants are equally advantageous and, at the same time, indistinguishable. The final order for expert E3 (academic expert) indicates that alternatives W1 and W2 are optimum and, at the same time, indistinguishable and that they outrank alternative W3.

MCDM methods consider the preferences of decision-makers, they will present a set of subjective solutions. In this case, one can easily observe the areas that the decisionmakers considered most relevant, depending on the functions they performed. Thus, the relative importance defined by experts E1 and E2, was associated mostly with economic and technical and operational parameters which directly affect the production costs and the financial performance of the mine. As regards the decision-maker E3, apart from the cost-related criterion, which was classified as the most important one, relative importance was evenly distributed among the remaining criteria at an average level. Decision-maker E4 focused chiefly on negative environmental impacts of the mining plant on its surroundings and it becoming a source of nuisance. 
The presented multi-aspect analysis of the issue enables us to find a compromise solution and to identify the most important criteria, both in terms of mine performance and its environmental impacts. Accordingly, the most advantageous variant was selected (W1) and the least favorable variant W3 was firmly rejected.

\section{Discussion}

This study explores the application of a multiple-criteria decision-making (MCDM) method, or more specifically, one of the available tools within this approach-ELECTRE III-to solving problems that involves the selection and assessment of mining machinery under specific rock mining conditions. The presented ELECTRE III method proves useful in solving problems related to the assessment of mining equipment performance, and the final results obtained indicate the desired directions of operation.

The results of all analyses show that alternative W1 has an advantage over all other alternatives. Alternative W1 meets nearly all key criteria emphasized by experts in the field on surface mining, academic experts and local government official expert on environment. Moreover, this alternative outranks all other alternatives in terms of process-related costs-a criterion that has been given the highest relative importance by E1, E2 and E3 decisionmakers. The criteria with the highest level of importance, according to most decisionmakers, were as follows: K4-Distance of the crushing unit from residential buildings (7.5 points), K1-Length of transport routes (7.0 points) and K8-Process-related costs (7.0 points). It is also important to note the high rank of alternative W1 compared to other criteria and its relation to other alternatives in expert assessments.

\section{Conclusions}

The set of criteria adopted to evaluate and select the mining equipment are largely those applicable to all types of selection problems. Hence a comprehensive analysis of a decision-making problem uses a set of task-specific criteria, taking into account technological, economic, environmental operational aspects as well as reliability.

The proposed method could be universally applicable in a number of mines, especially when the fleet of machines is to be replaced. This method allows the experts to conduct a rigorous analysis of the issue and gain information basing on results the outputs obtained at intermediate levels.

In addition, ELECTRE III offers the decision-maker an opportunity to define the local preference model in each node of the hierarchy, according to their objectives and taking into account the specific feature of the sub-problem. Furthermore, the analysis has clearly demonstrated that an improved layout and configuration of machine systems will result in lower costs, both in terms of capital expenditure and, last but not least, also operating costs.

Despite the specificity related to reduced profitability of low-quality deposits exploitation, the implementation of the MCDM presented no major difficulties, which proves its universality.

Author Contributions: Conceptualization, M.P. and P.B.; methodology, P.B.; software, P.B.; validation, M.P., P.B. and Z.K.; formal analysis, Z.K.; investigation, M.P. and P.B.; resources, M.P.; data curation, M.P.; writing — original draft preparation, P.B., M.P. and Z.K.; writing—review and editing, Z.K.; visualization, M.P.; supervision, Z.K. All authors have read and agreed to the published version of the manuscript.

Funding: This research was funded by AGH University of Science and Technology, Faculty of Mining and Geoengineering; subsidy number: 16.16.100.215.

Institutional Review Board Statement: Not applicable.

Informed Consent Statement: Not applicable.

Data Availability Statement: The data can be accessed upon request any of the authors.

Conflicts of Interest: The authors declare no conflict of interest. 


\section{References}

1. Bodziony, P.; Kasztelewicz, Z.; Sawicki, P. The Problem of Multiple Criteria Selection of the Surface Mining Haul Trucks. Arch. Min. Sci. 2016, 61, 223-243. [CrossRef]

2. Stevanović, D.; Lekić, M.; Kržanović, D.; Ristović, I. Application of MCDA in selection of different mining methods and solutions. Adv. Sci. Technol. Res. J. 2018, 12, 171-180. [CrossRef]

3. Bazzazi, A.A.; Osanloo, M.; Karimi, B. A new fuzzy multi criteria decision making model for open pit mines equipment selection. Asia-Pac. J. Oper. Res. 2011, 28, 279-300. [CrossRef]

4. Burt, C.N.; Caccetta, L. Equipment Selection for Surface Mining: A Review. Interfaces 2014, 44, 143-162. [CrossRef]

5. Voronov, Y.; Voronov, A.; Voronov, A. Quality criterion of the loading and transport system operation at open-pit mines. E3S Web Conf. 2019, 105. [CrossRef]

6. Samanta, B.; Sarkar, B.; Mukherjee, S.K. Selection of Opencast Mining Equipment by Multi-Criteria Decision-Making Process. Min. Technol. 2002, 111, 136-142. [CrossRef]

7. Haldar, S.K. Chapter 12-Elements of Mining, Mineral Exploration (Second Edition). Princ. Appl. 2018, $229-258$.

8. Petlovanyi, M.V.; Lozynskyi, V.H.; Saik, P.B.; Sai, K.S. Modern experience of low-coal seams underground mining in Ukraine. Int. J. Min. Sci. Technol. 2018, 28, 917-923. [CrossRef]

9. Pimentel, B.S.; Gonzalez, E.S.; Barbosa, G.N.O. Decision-support models for sustainable mining networks: Fundamentals and challenges. J. Clean. Prod. 2016, 112, 2145-2157. [CrossRef]

10. Capasso, I.; Lirer, S.; Flora, A.; Ferone, C.; Cioffi, R.; Caputo, D.; Liguori, B. Reuse of mining waste as aggregates in fly ash-based geopolymers. J. Clean. Prod. 2019, 220,65-73. [CrossRef]

11. Segura-Salazar, J.; Tavares, L.M. Sustainability in the Minerals Industry: Seeking a Consensus on Its Meaning. Sustainability 2018, 10, 1429. [CrossRef]

12. Patyk, M.; Bodziony, P.; Kasztelewicz, Z. Analysis of quarrying equipment operating cost structure. J. Pol. Miner. Eng. Soc. 2019, 21,311-318.

13. Mudd, G.M. The Environmental sustainability of mining in Australia: Key mega-trends and looming constraints. Resour. Policy 2010, 35, 98-115. [CrossRef]

14. Moore, K.R.; Whyte, N.; Roberts, D.; Allwod, J.; Leal Ayala, D.; Bertrand, G.; Bloodworth, A.J. The re-direction of small deposit mining: Technological solutions for raw materials supply security in a whole systems context. Resour. Conserv. Recycl. X 2020, 7. [CrossRef]

15. Siksnelyte-Butkiene, I.; Zavadskas, E.K.; Streimikiene, D. Multi-Criteria Decision-Making (MCDM) for the Assessment of Renewable Energy Technologies in a Household: A Review. Energies 2020, 13, 1164. [CrossRef]

16. Kumar, A.; Sah, B.; Singh, A.R.; Deng, Y.; He, X.; Kumar, P.; Bansal, R.C. A review of multi criteria decision making (MCDM) towards sustainable renewable energy development. Renew. Sustain. Energy Rev. 2017, 69, 596-609. [CrossRef]

17. Trojanowska, M.; Nęcka, K. Selection of the Multiple-Criiater Decision-Making Method for Evaluation of Sustainable Energy Development: A Case Study of Poland. Energies 2020, 13, 6321. [CrossRef]

18. Hokkanen, J.; Salminen, P. ELECTRE III and IV Decision Aids in an Environmental Problem. J. Multi-Criteria Decis. Anal. 1997, 6, 215-226. [CrossRef]

19. Mutlu, M.; Sari, M. Kullanimi multi-criteria decision making methods and use of in mining industry. Sci. Min. J. 2017, 4, 181-196.

20. Sitorus, F.; Cilliers, J.; Brito-Parada, R. Multi-criteria decision making for the choice problem in mining and mineral processing: Applications and trends. Expert Syst. Appl. 2019, 121, 393-417. [CrossRef]

21. De Sousa, W.T., Jr.; Souza, M.J.F.; Cabral, I.E.; Diniz, M.E. Multi-Criteria Decision Aid methodology applied to highway truck selection at a mining company. Rem. Rev. Esc. Minas 2014, 67, 285-290. [CrossRef]

22. Stojanovic, C.; Bogdanovic, D.; Urosevic, S. Selection of the optimal technology for surface mining by multi-criteria analysis. Kuwait J. Sci. 2015, 42, 170-190.

23. Vujic, S.; Hudej, M.; Miljanovic, I. Results of the promethee method application in selecting the technological system at the majdan III open pit mine. Arch. Min. Sci. 2013, 58, 213-219.

24. Hodgett, R.E. Comparison of Multi-Criteria Decision-Making Methods for Equipment Selection. Int. J. Adv. Manuf. Technol. 2016, 85, 1145-1157. [CrossRef]

25. Figueira, J.R.; Greco, S.; Roy, B.; Slowinski, R. An overview of ELECTRE methods and their recent extensions. J. Multi-Criteria Decis. Anal. 2013, 20, 61-85. [CrossRef]

26. Roy, B. The Outranking Approach and the Foundations of ELECTRE Methods. Readings in Multiple Criteria Decision Aid. Bana e Costa C.A.; Springer: Berlin, Germany, 1990; pp. 155-183.

27. Roy, B. Decision Aid and Decision Making. Eur. J. Oper. Res. 1990, 45, 324-331. [CrossRef]

28. Roy, B. Wielokryterialne Wspomaganie Decyzji; Wydawnictwo Naukowo-Techniczne: Warszawa, Poland, 1990.

29. Vincke, P. Multicriteria Decision-Aid; John Wiley \& Sons: Chichester, UK, 1992.

30. Vincke, P. Outranking Approach. In Multicriteria Decision Making; Gal, T., Stewart, T.J., Hanne, T., Eds.; International Series in Operations Research \& Management Science; ISOR: Boston, MA, USA, 1999; Volume 21, pp. 305-333.

31. Sawicki, P. Wielokryterialny dobór operatora usług logistycznych. Logistyka 2001, 4, 59-66.

32. Govindan, K.; Brandt Jepsen, M. ELECTRE: A comprehensive literature review on methodologies and applications. Eur. J. Oper. Res. 2016, 250, 1-29. [CrossRef] 
33. Bodziony, P.; Patyk, M.; Kasztelewicz, Z. Multi-criteria decision making for the choice equipment in mining with application of AHP method. New trends in production engineering: Monograph. Soc. Sci. 2019, 48-59.

34. Caterpillar Performance Handbook; 48th ed.. Caterpillar Inc.: Peoria, IL, USA, 2018. Available online: https://wheelercat.com/wpcontent/uploads/2018/07/SEBD0351_ED48.pdf (accessed on 1 March 2021).

35. Specification @ application Handbook; Edition 31. Komatsu Ltd.: Komatsu, Japan, 2013. Available online: https://www. directminingservices.com/wp-content/uploads/2011/05/Edition31.pdf (accessed on 1 March 2021).

36. Powerscreen 1180 Premiertrak Jaw Crusher Specification-Rev 6. 01/01/2015. Available online: http://csrpower.com.my/ details / Powerscreen\%201180\%20Premiertrak.pdf (accessed on 1 March 2021).

37. EMEP/EEA Air Pollutant Emission Inventory Guidebook 2019; EEA Report; EEA: Luxembourg, 2019; Volume 13. 